\title{
Effectiveness of Adaptation Measures Taken by Farmers in the Field of Effects of Climate Change in the Coastal Department in Benin
}

\author{
Acacha-Acakpo Hortensia V. ${ }^{1}$, Seboka Siriac A. ${ }^{2}$ \\ ${ }^{1}$ The Benin School of Applied Economics and Management (ENEAM/UAC) \\ ${ }^{2}$ Institute of Mathematics and Physics (IMSP/UAC)
}

\begin{abstract}
It is evident that climate change affects the well being of farmers and increases their vulnerability in the future if no action is taken into account by them. In fact, Various adaptation measures, such as crop diversification, changes in the dates of semi and crops, use of seed and fertilizer varieties, irrigation, use of tractors etc. are carried out by Farmers. However, these different measures have not yet had the same effect in reducing the negative effects of climate change on agriculture. Thus, this paper aims at evaluating empirically assess the effectiveness of these measures or strategies of adaptations on the performance of farms in Benin. Using the estimation technique of MCO, estimating the technical efficiency of farmers' production reveals that the use of improved seeds and fertilizers also reduces the negative impact of climate change In addition, land irrigation and the number of weeding remain influential factors for which we do not have the necessary statistics to assess their efficiencies
\end{abstract}

Keyswords- Efficiency, farmers, climate change, coastal.

Résumé : Efficacité des mesures d'adaptations prises par les agriculteurs face aux effets du changement climatique dans le département de Littoral au Benin

Il est évident que le changement climatique affecte le bien être des agriculteurs et accroit leur vulnérabilité dans le futur si aucune mesure n'est prise en compte par ces derniers. A cet effet, divers mesures d'adaptations, comme la diversification des cultures, la modification des dates de semi et de récoltes, l'utilisation de variété de semences et d'engrais, l'irrigation, utilisation des tracteurs etc sont pratiqués par les agriculteurs. Toutefois ces différentes mesures n'ont pas encore les mêmes effets en termes de réduction des effets négatifs du changement climatique sur l'agriculture. Ainsi, notre travail a pour objectif d'évaluer empiriquement l'efficacité de ces mesures ou stratégies d'adaptations sur la performance des exploitations agricoles au Bénin. En utilisation la technique d'estimation des MCO, l'estimation de l'efficacité technique de production des agriculteurs révèle que l'utilisation des semences améliorées et des engrais réduisent l'impact négatif du changement climatique. En outre l'irrigation des terres et le nombre de sarclage restent des facteurs influents dont nous n'avons des statistiques nécessaires pour apprécier leurs efficacités.

Mots clés: Efficacité, agriculteurs, changement climatiques, littoral.

\section{INTRODUCTION}

Climate change today is a potentially major threat to the environment and sustainable development. According to report $\mathrm{N}^{\circ} 4$ of the Intergovernmental Panel on Climate Change (GIFC), they are manifested through various trends such as rising temperatures, rising sea levels, increased variability in rainfall And the characteristics of the agricultural seasons, an upsurge of extreme phenomena such as droughts and floods, etc. Indeed, global observations show a general upward trend $\left(0,6^{\circ} \mathrm{C}\right.$ or $-0.2^{\circ} \mathrm{C}$ ) of the mean surface temperature which is linear and almost two times that of the period from 1906 to 2005 compared to 1956 to $2005,0.13^{\circ} \mathrm{C}$ per decade (CRA, 2010). In addition, Veolia's environmental report $\mathrm{N}^{\circ} 7$ shows that world cereal production will fall by $5 \%$ for a $2^{\circ} \mathrm{C}$ increase.

Africa and Western Asia would see their production fall by $25 \%$ for $3^{\circ}$ to $4^{\circ} \mathrm{C}$ rise in average temperature and famine would affect 500 million more people. To this is added the acidification of the oceans which threatens the formation of shells and skeletons. But the world's population depends on the products of the sea and agriculture, which, with a social weight that goes well beyond the $3 \%$ to $5 \%$ of the gross domestic product in the developed economies, will continue to support the strong A fraction of the world's population that lives on less than US \$ 2 per day. At the health level, there have been degradations in the hot regions which, on average, have resulted in an additional 150000 deaths per year since 1970. 
The diagnosis made on the effects of climate change in Benin's investment report (2008) shows that the agroecological zones in the central and northern parts of the country are vulnerable to the three major climatic risks of drought, late rains and Violent and flooding. Heavy winds and excessive heat are likely to be of great importance in some localities with high resource exposure (catchment areas, subsistence agriculture and water resources) and social groups such as smallholder farmers, Emerging Farmers and Fishermen In the south these regional climatic risks are in descending order of importance, floods, violent and late rains and drought. The most exposed resources are food crops, land and biodiversity and water resources. The most exposed social groups are small-scale farmers, fishermen and stockbreeders.

West Africa, which accounts for more than $43 \%$ of the total population of sub-Saharan Africa, is severely affected by climate change. Indeed, the observations reveal that the UEMOA zone has experienced a rise in temperatures of 0.6 to $0.7^{\circ} \mathrm{C}$, faster than the overall average. Over the past few decades, space, mostly semiarid agricultural land in its northern zone, has experienced extreme variability and a marked decrease in precipitation. Similarly, there is a disturbing rise in sea level, on the order of 1 to $2 \mathrm{~mm}$ per year, in all the countries of the Union, such as Benin, as a consequence of the rise in temperature. Such as coastal erosion, salinization of land associated with marine intrusion, severity of drought and devastating flooding that caused damage estimated at US \$ 189 million and US \$ 388 billion respectively for the minimum and maximum scenario. In addition, the projections for 2010 indicate that this region could experience a warming in the order of 3 to $6^{\circ} \mathrm{C}$. Despite uncertainties, future trends in rainfall indicate a decline of up to $20-30 \%$, particularly in the western part of the union. And finally, the sea level could rise from $0.5 \mathrm{~m}$ to $0.9 \mathrm{~m}$ (BOAD, 2010).

In Benin, three climatic subsets are distinguished: The occurrence of a rainfall recession extending on JulyAugust induces a regime with four seasons: a major rainy season from April to July, a small dry season in August To September, a small season of rains of October of November and a great dry season from December to March. In addition, long-term hydrological observations show a general decline in average rainfall of about 15 $30 \%$ depending on the area and a decrease in the number of rainy days and the duration of rainy seasons, in surface waters at the level of the main basins (40 to 60\%). Under these conditions of farming and the use of current species and varieties, research results indicate that the yield level of Beninese agriculture is below the potential of cultivated varieties. A comparative analysis shows a considerable drop in harvests of the order of 3 to $18 \%$ for all crops combined. The increase in heavy rains due to climate change resulted in the destruction of 25,000 ha of food crops and 1204 ha of cotton fields with approximately 674 affected producers and estimated damage of 9.4 billion CFA francs (DANIDA 2008).

As for food prices, floods have led to a scarcity of food products, with the consequent occurrence of inflationary pressures in the last quarter of 2010 and the first quarter of 2011. But the impact on public finances has been limited in Due to strong support from the international community and several local companies and charitable associations that benefited the Beninese State.

While, the Beninese economy despite the efforts made to a GDP which remains dissolved of the minimum rate of $7 \%$ required to reach the MDGs. It is characterized by a strong predominance of the primary sector, which occupies about $60 \%$ of the population and contributes to $36.6 \%$ of GDP. Moreover, according to human poverty indicators, $4.3 \%$ of the Beninese population is affected by human poverty (MEHU, 2011).

Faced with this situation, several strategies are adopted by farmers to counteract the difficulties. It is therefore necessary to analyze the effectiveness of these strategies in order to deduce the most effective ones.

\section{THEORETICAL FRAMEWORK ON CLIMATE CHANGE AND ECONOMIC GROWTH \\ $\Rightarrow$ Concept of climate change (definition and causes)}

By climate change, the GIEC intends any climate change in the time it is due to natural variability or human activities. This definition does not differ from that of the United Nations Framework Convention on Climate Change (UNFCCC) in Article 1, where climate change is understood to mean variations in climate directly or indirectly due to human activity that alters the composition of the global atmosphere and add to the observed natural climate variability of comparable periods (UNFCCC, 1992). Choisnel (1992), quoted by Johnson (1997) will go further by putting much more emphasis on the energy balance of the Earth-ocean-atmosphere system. For him, climate change is large enough to correspond to a significant change in the energy balance of the EarthOceans-Atmosphere system, leading to a change. However, in our study, climate change means changes in temperature and precipitation, whether natural or anthropogenic.

2.1 Concept of vulnerability in terms of climate change In the climate context, according to IPCC (2007), vulnerability is the degree to which a system is able to cope with the adverse effects of climate change (including 
climate variability and extremes). It describes the extent to which a system is sensitive and unable to cope with the adverse effects of climate change, whether climate variability or meteorological extremes (Nelson et al., 2002). Vulnerability depends on the character, magnitude and pace of climate change, variations in the system, sensitivity and adaptive capacity (IPCC, 2007). The degree of vulnerability for an individual, household or group of people is determined by their exposure to risk factors and their ability to cope with crisis situations.

\subsection{Adaptation to climate change}

Climate change creates risks but also compensatory strategies around the world. Individuals and companies can take advantage of opportunities and reduce risks if they understand, plan and adapt to climate change. The effects of climate variability and climate change are potentially greater for the poor in developing countries than for rich countries. Vulnerability to the impacts of climate change is a function of exposure to climate variables, sensitivity to these variables and the adaptive capacity of the affected community. Often the subsistence of the poor population depends on economic activities that are climate sensitive. For example, agricultural and forestry activities depend on weather and local climatic conditions; a change in these conditions could have a direct impact on productivity levels and reduce substances. The concept of adaptation can be understood as the adjustment of natural systems and human systems to a changing environment or environment. Adaptation to climate change indicates the adjustment of natural and human systems in response to current or future climateinduced stimuli in order to mitigate adverse effects or exploit beneficial opportunities (IPCC 2007). This adaptation consists of a set of readjusted or self-operated readjustments within natural and human systems in curative or preventive responses to current or future climate stimuli or their effects in order to mitigate their nuisance or wholly appropriately Profit (Issa, 1995). Thus, the adaptation can be carried out in two different ways

Climate change interventions require a two-pronged approach to reduce greenhouse gas emissions (climate change mitigation measures) as well as activities and practices to reduce our vulnerability to potential impacts (measures of adaptation). Mitigation measures are needed to reduce the pace and magnitude of climate change on a global scale. However, in themselves. These measures do not prevent climate change. In the poorest countries. Adaptation is largely a matter of effort, autonomy and personal initiative. Millions of people who have barely sufficient resources to feed, clothe and shelter their families are forced to allocate funds and work to accommodate them. In the agriculture sector, adaptation requires the use of good agricultural, forestry and fisheries practices to cope with changing and harsher environmental conditions. Adaptation in agriculture is illustrated in particular by changes in the timing of planting or planting, the adoption of new technologies, and the promotion of agricultural biodiversity (FAO, 2007).

The literature on coping strategies is very abundant. As an example, in Bangladesh, women farmers build "floating gardens" of hyacinth rafts on which vegetables can be grown in flood-prone areas. In Sri Lanka, farmers experiment with rice varieties that can resist the saline intrusion and reducing the amount of water. The development of adaptation strategies is an inescapable way to reduce the damage expected in the short term (Pielke, 1998). However, adaptation could be achieved through technological innovation.

\subsection{Economic Foundations}

The issue of climate change is largely due to its global public good character. As with any public good, decentralized market systems do not provide a socially optimal supply. By its global nature, an adequate public policy presupposes the voluntary restriction of sovereignty for States under negotiated agreements.

The provision of global public goods can be used under two management regimes. The most extreme is the uncooperative regime without international agreements. This is the case for climate change until today. In these Situations, countries and individuals tend to act according to their own interests, and the overall balance resulting from their decisions is non-cooperative in nature. Although perfect cooperation is difficult to obtain, the World Trade Organization (WTO) or the Montreal Protocol is approaching this ideal by promoting free and open trade in the former case, or the disappearance of the chemicals responsible for Reduction of the ozone layer in the second. A cooperative regime must set an effective objective for the provision of the global public good, include the most important countries in an agreement, put in place means of monitoring and compliance with commitments, and create strong incentives Signatory parties. The reluctance of the main countries responsible largely for the emission of greenhouse gases explains the main difficulty for the establishment of such a regime in order to resolve the issue of climate change.

\section{METHODOLOGY OF THE STUDY}

The analysis presented focuses on the effectiveness of farmers' adaptation to climate change in the Littoral department in Benin. The analysis would have wanted to be on a time series but for lack of data and oblivion of the 
respondents, we performed a snapshot analysis. In the absence of statistical data for our analyzes after a literature search, a survey allowed us to collect data.

\subsection{Sampling}

In the Littoral department of Benin, vegetable growing is the most practiced and more vulnerable to climate change.
So the population of this study is made up of all the Market gardeners of the department. The sampling rate is set at $10 \%$. The different sampling data are presented in Table 1.

Table.1: Sampling data

\begin{tabular}{|l|c|c|c|c|c|c|c|}
\hline Sites & $\begin{array}{l}\text { Site of } \\
\text { Houéyiho }\end{array}$ & $\begin{array}{l}\text { Site of Palais } \\
\text { des congrès }\end{array}$ & $\begin{array}{l}\text { Site of } \\
\text { FIFADJI }\end{array}$ & $\begin{array}{l}\text { Site of } \\
\text { Cadjèhoun }\end{array}$ & $\begin{array}{l}\text { Site of } \\
\text { UAC }\end{array}$ & $\begin{array}{l}\text { Other } \\
\text { Site }\end{array}$ & $\begin{array}{l}\text { Total } \\
\text { Mother Population }\end{array}$ \\
\hline sample & 200 & 60 & 20 & 50 & 3 & 40 & 373 \\
\hline
\end{tabular}

$\Rightarrow$ Investigation

It consisted in collecting the data necessary for the analysis. These are the data on the various adaptive measures taken by farmers in the face of climate change. This survey was carried out by means of a fact sheet, the body of which is shown in Table 2.

Table.2: Survey form template

\begin{tabular}{|c|c|c|c|c|c|c|c|c|}
\hline${ }^{\mathscr{e}}$ & 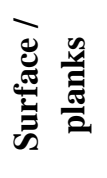 & 总 & 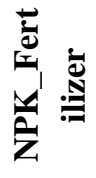 & 离 & 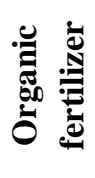 & 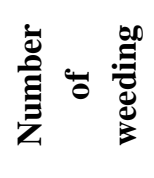 & 离 & $\underset{\Xi}{\mathscr{E}}$ \\
\hline \multicolumn{9}{|l|}{ Tomato } \\
\hline \multicolumn{9}{|l|}{ Pepper } \\
\hline Leafy vegetables & & & & & & & & \\
\hline
\end{tabular}

The data from the survey were first presented in tables using the Excel software (see Appendix), and then imported into the Eviews7 software for regressions.

\subsection{Modeling}

The modeling can be summarized in two phases, namely the phase of the choice of the model and the variables and that of the estimation of the model.

\subsubsection{Form of the model and choice of variables}

For the verification of our hypothesis we start from the Cobb Douglas model which is as follows:

$$
Y=A K^{\alpha} L^{\beta}
$$

With Y the total output or income level, $\mathrm{K}$ the invested capital and $\mathrm{L}$ the amount of labor used. Applying the logarithm function to this model, its econometric form gives us its linear form which follows:

Or:

$$
\mathrm{y}=\mathrm{c}+\alpha \ln \mathrm{Li}+
$$$$
\beta \ln K i+\mu \mathrm{i}
$$ 


$$
\begin{aligned}
& \mathrm{D}_{1}=\left\{\begin{array}{c}
\mathbf{1} \text { if there is more feritlity compared to the } \\
\text { average }
\end{array}\right. \\
& 0 \text { if not } \\
& D_{2}=\left\{\begin{array}{c}
1 \text { if there is less feritlity compared to the } \\
\text { average } \\
0 \text { if not }
\end{array}\right.
\end{aligned}
$$

The residue graph allowed us to determine these values. The pairs above the corridor are associated with $\mathrm{D}_{1}$ and those below it are associated with $\mathrm{D}_{2}$. Thus, the estimation model becomes:

$$
\text { Income }=\mathrm{C}(1)+\mathrm{C}(2) * \mathrm{NPK} \_ \text {fertilizer+ }
$$

$\mathrm{C}(3) *$ Urea_fertilizer $+\mathrm{C}(4) *$ Organic_fertilizer $+\mathrm{C}(5)^{*}$

Number of weeding $+\mathrm{C}(5) * \mathrm{D} 1+\mathrm{C}(6) * \mathrm{D} 2+\mu \mathrm{i}$

With $\mu$ i the error term.

Knowing the values of the variables explained and the explanatory variables of the model, we will estimate the values of the coefficients by simple linear regression and judge their statistical significance by the Ordinary Least Squares (OLS) method. The significance threshold used is $5 \%$ and a coefficient will be said to be significant when the probability associated with it is less than 0.05 . Estimates are made in an instant cross-section on observations from 2016. The OLS estimate is based on fundamental assumptions. For this purpose the validation tests will be carried out before interpreting the estimated coefficients. The following tests will be carried out: $\checkmark$ Residue normality test: It is on this test that the validity of the other tests rests, therefore the errors must follow a normal law for the validity of the latter.

$\checkmark$ Residue heteroskedasticity test;

$\checkmark$ Autocorrelation test to put us in perfume that no bias has slipped into the estimation of the parameters.

The estimates are made under Eviews 7.

\section{PRESENTATION OF THE MODEL ESTIMATE RESULTS}

The estimation of each study design is done using the Eviews7 software. The results are presented below.

\subsection{Synthesis 1}

The use of NPK, urea and organic fertilizers is relatively effective in the face of climate change for the cultivation of chilli in the littoral in Benin. The results are presented in Tables 3 and 4.

Table.3: Summary of Estimate Results: Chili Peppers

\begin{tabular}{|l|c|c|c|}
\hline \multicolumn{1}{|c|}{ Variable } & Coefficient & t-Statistic & Prob. \\
\hline C & 1623.258 & 0.043106 & 0.9659 \\
\hline NPK_fertilizer & 3926.324 & 3.202702 & 0.0033 \\
\hline Urea_fertilizer & 6179.001 & 2.450954 & 0.0205 \\
\hline Organic_fertilizer & 4013.529 & 2.296449 & 0.0291 \\
\hline Number of weeding & 1881.758 & 0.330636 & 0.7433 \\
\hline D1 & 163243.5 & 9.709467 & 0.0000 \\
\hline D2 & -98988.05 & -6.183171 & 0.0000 \\
\hline R-Squared ( $\left.{ }^{2}\right)$ & \multicolumn{3}{|c|}{0.907109} \\
\hline Pro associé à F & \multicolumn{3}{|c}{0.000000} \\
\hline
\end{tabular}

Table.4: Residual tests on the pepper model

\begin{tabular}{|l|l|l|}
\hline Test & Probability & Decision \\
\hline Normality of Jarque-Bera & 0,565339 & Normality \\
\hline Autocorrelation of Breusch-Godfrey & 0,4942 & Non-autocorrelated \\
\hline White Heteroskedasticity & 0,1080 & Homoscédastic \\
\hline
\end{tabular}


The analysis of Tables 3 and 4 shows that the estimation of the tomato model resulted in the following results: Income $=1623.25+3926.32 * \mathrm{NPK}$ _fertilizer + 6179.00*Urea_fertilizer $+4013.52 *$ Organic_fertilizer + $1881.75 *$ Number of weeding $+163243.50 * \mathrm{D} 1-$

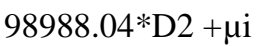

With $\mu \mathrm{i}$ the error term.

The results obtained allow us to assess the quality of the regression and the significance of the variables explained. Indeed, the coefficient of determination $\mathrm{R}^{2}=0.907109$ indicates that the quality of the regression of the model is satisfactory. The effectiveness of adaptation measures for tomato crops in the face of climate change is more than
$90 \%$ explained by the explanatory variables. The model is globally significant (Pro associated with $\mathrm{F}=$ 0.0000). NPK fertilizer, fertilizer Urea, organic fertilizer are significant at the $5 \%$ threshold. It is also noted that the indicator variables are also significant at the 5\% threshold. Only the number of weeding is not significant at the 5\% threshold. A $1 \%$ increase in NPK, Urea, Organic fertilizer leads respectively to an increase of $39.26,61.79$ and 40.13 of income.

\subsection{Synthesis 2}

Tables 5 and 6 conclude that the use of NPK and organic fertilizer is relatively effective in the face of climate change for tomato growing in the Littoral in Benin

Table.5: Summary of Estimate Results: Tomato Cases

\begin{tabular}{|l|c|c|c|}
\hline \multicolumn{1}{|c|}{ Variable } & Coefficient & t-Statistic & Prob. \\
\hline C & 27076.14 & 0.635181 & 0.5298 \\
\hline NPK_fertilizer & 6742.687 & 2.070373 & 0.0466 \\
\hline Organic_fertilizer & 8266.683 & 3.794063 & 0.0006 \\
\hline Number of weeding & -121.9476 & -0.019269 & 0.9847 \\
\hline D1 & 179674.1 & 5.748856 & 0.0000 \\
\hline R-Squared $\left(\mathrm{R}^{2}\right)$ & \multicolumn{3}{|c|}{0.794555} \\
\hline Pro associé à F & \multicolumn{3}{|c|}{0.000000} \\
\hline
\end{tabular}

Table.6: Residual tests on the Tomato model

\begin{tabular}{|l|l|l|}
\hline Test & Probability & Décision \\
\hline Normality of Jarque-Bera & 0,504029 & Normality \\
\hline Autocorrelation of Breusch-Godfrey & 0,5615 & Non-autocorrelated \\
\hline White Heteroskedasticity & 0,2959 & Homoscédastic \\
\hline
\end{tabular}

Analysis of Tables 5 and 6 shows that the estimation of the tomato model resulted in the following results:

Income $=27076.13+6742.68 * \mathrm{NPK}$ _fertilizer + $8266.68 *$ Organic_fertilizer - $121.94 *$ Number of weeding $+179674.08 * \mathrm{D} 1+\mu \mathrm{i}$

With $\mu$ i the error term..

The coefficient of determination $\mathrm{R}^{2}=0.794555$ indicates that the quality of the regression of the model is satisfactory. The effectiveness of adaptation measures for tomato crops in the face of climate change is explained by more than $79 \%$ of the explanatory variables.

The model is globally significant (Pro associated with $\mathrm{F}=$ 0.0000). The fertilizer NPK, organic fertilizer are significant at the threshold of 5\%. It is also noted that the indicator variable is also significant at the 5\% threshold. Only the number of weeding is not significant at the $5 \%$ threshold. A $1 \%$ increase in NPK, Organic fertilizer leads respectively to an increase of 67.42 and 82.66 of the income.

\subsection{Synthesis 3}

The use of urea, organic fertilizer and improved seed is relatively effective in the face of climate change for leafy vegetable growing in the Littoral region of Benin. The results are presented in Tables 7 and 8 .

Table.7: Summary of estimation results: leafy vegetable (cabbage, shillo, large nightshade, reading sheet)

\begin{tabular}{|l|r|r|r|}
\hline \multicolumn{1}{|c|}{ Variable } & Coefficient & \multicolumn{1}{c|}{ t-Statistic } & \multicolumn{1}{c|}{ Prob. } \\
\hline C & -17467.49 & -0.669992 & 0.5074 \\
\hline Organic_fertilizer & 29346.12 & 14.19506 & 0.0000 \\
\hline Improved seeds & 2687.541 & 2.749119 & 0.0095 \\
\hline Urea_fertilizer & 32884.16 & 23.91246 & 0.0000 \\
\hline
\end{tabular}




\begin{tabular}{|l|c|c|c|}
\hline Number of watering & 3722.608 & 0.678818 & 0.5018 \\
\hline R-Squared $\left(\mathrm{R}^{2}\right)$ & \multicolumn{3}{|c|}{0.992905} \\
\hline Pro associé à F & \multicolumn{3}{|c|}{0.000000} \\
\hline
\end{tabular}

Table.8: Residual tests on leaf vegetable model

\begin{tabular}{|l|c|l|}
\hline Test & Probability & Decision \\
\hline Normality of Jarque-Bera & 0,504029 & Normality \\
\hline Autocorrelation of Breusch-Godfrey & 0,5615 & Non-autocorrelated \\
\hline White Heteroskedasticity & 0,2959 & Homoscédastic \\
\hline
\end{tabular}

Analysis of Tables 7 and 8 shows that the estimation of the tomato model resulted in the following results:

Income $=-17467.48+29346.12 *$ Oganic_fertilizer + $2687.54 *$ improved leeds $+32884.15 *$ Urea_fertilizer + $3722.60 *$ Number of weeding $+\mu \mathrm{i}$

With $\mu \mathrm{i}$ the error term.

The coefficient of determination $\mathrm{R}^{2}=0.992905$ indicates that the quality of the regression of the model is satisfactory. The effectiveness of adaptation measures for tomato crops in the face of climate change is more than $90 \%$ explained by the explanatory variables. The model is globally significant (Pro associated with $\mathrm{F}=$ 0.0000). Urea fertilizer, organic fertilizer and improved seeds are significant at the $5 \%$ threshold. Only the number of watering is not significant at the 5\% threshold. A $1 \%$ increase in organic fertilizer, improved seed and urea fertilizer respectively results in an increase of 29.34 , 26.87 and 32.88 of income.

\section{COMMENT}

Vegetable crops are more vulnerable to climate change in Benin, especially in the department of Littoral. The Market gardeners of this department, have taken several measures to deal with this crucial problem which continues to reduce their incomes. These measures include the use of chemical fertilizers (NPK, urea), organic fertilizers, irrigation, the use of improved seeds, etc. After the surveys, the analyzes of our different results indicate the effectiveness of the measures taken for each of the categories of crops selected for this study in the Littoral. Indeed, for the cultivation of Pepper, the use of fertilizers NPK, urea, and organic is relatively effective in the face of climate change. For this crop, it should also be noted that the watering of the pepper crop is done twice a day (according to all the respondents). This measure is undoubtedly a sine qua none measure for the monitoring of the culture because the pepper very vulnerable to global warming. More than a measure, watering crops is crucial. We do not have the statistics necessary to confirm or invalidate the effect of the weeding number. Then, for tomato growing, the use of NPK fertilizer, and organic is relatively effective in dealing with climate change. Watering is also considered as a capital measure and taken in the way by all Market gardeners (twice a day). No surveyed harvesters use urea for tomato production. Nor do we have the statistics necessary to (8) confirm or deny the effectiveness of the number of weeding. Finally, for the cultivation of vegetables (cabbage, Chillo, large nightshade, reading sheet) the use of urea, organic fertilizer and improved seed is relatively effective in the face of climate change. According to our surveys, Market gardeners do not water the same number of times their crops. The number of watering varies from 2 to 4 or 5 per day. But we do not have the necessary statistics to invalidate or confirm its effectiveness.

In summary, the use of NPK fertilizers, urea, organic, irrigation, and improved seeds are measures that positively affect income despite climate change. These measures taken by farmers are therefore effective in the face of climate change in the Littoral department in Benin.

\section{REFERENCES}

[1] Choisnel E. (1992) "Droughts and their diagnoses".

[2] Jonhson E. (1997) "Changes in Earnings Inequality: The Role of Demand Shifts"

[3] NELSON G. C. (2009) "Climate change and agriculture" international food policy, Research institute.

[4] Pielke R. (1998) "Rethinking the role of adaptation in climate policy".

[5] BENIN (2008) "National Investment Report" high level conference on: water for agriculture and energy in Africa: the challenges of climate change. Syrte, Libyan Arab Jamahiriya, 15-17 December 2008. BOAD (2010) "Climate change and food security in the WAEMU zone: current and future challenges, impacts and challenges" final report, July 2010.

[6] CAE (2012): "Report on Inclusive Growth in Benin"

[7] CRA (2010) "The Sahel in the face of climate change: a challenge for sustainable development", monthly bulletin, special issue of the Inter-State Committee for Drought Control in the Sahel. 
[8] DANIDA (2008) "Assessing the Impacts of Climate Change on Development Programs for Cooperation with Benin". Presented by: baastel sprl, on 4 July 2008.

[9] MEHU (2011) "Second National Communication of Benin on Climate Change", Directorate of Environment, June 2011.

[10]FAO (2007): "Climate Change and Food Security" a Framework for Action Rome, 2007.

[11] IPCC (2007): Intergovernmental Panel on Climate Change fourth report. 